\title{
Coronavirus 2019, Thrombocytopenia and HELLP Syndrome: Association or Coincidence?
}

\section{Coronavírus 2019, trombocitopenia e síndrome HELLP: Associação ou coincidência?}

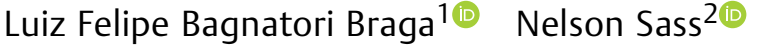 \\ ${ }^{1}$ Hospital Municipal Maternidade Escola de Vila Nova Cachoeirinha, \\ São Paulo, SP, Brazil \\ 2 Escola Paulista de Medicina, Universidade Federal de São Paulo, São \\ Paulo, SP, Brazil
}

\begin{abstract}
Address for correspondence Luiz Felipe Bagnatori Braga, MD, Hospital Municipal Maternidade Escola de Vila Nova Cachoeirinha, Av. Deputado Emílio Carlos, 3100, Vila Nova Cachoeirinha, São Paulo, SP, 02720-200, Brazil (e-mail: Ifbbraga@gmail.com).
\end{abstract}

Rev Bras Ginecol Obstet 2020;42(10):669-671.

\begin{abstract}
Keywords

- preeclampsia

- HELLP syndrome

- thrombocytopenia

- coronavirus infections

- pregnancy complications

\section{Resumo}

The present report describes the case of a 31-year-old primigravida, with dichorionic twins at 31 weeks. She presented with history of myalgia, jaundice, and abdominal discomfort. No flu-like symptoms as fever or cough. She was not aware of exposure to COVID-19. Normal blood pressure and $\mathrm{O}_{2}$ saturation. Laboratory tests showed platelet count of $218,000 \mathrm{~mm}^{3}$, alanine aminotransferase (ALT) $558 \mathrm{IU}$ and serum creatinine $2.3 \mathrm{mg} / \mathrm{dl}$. Doppler ultrasound in one twin was compatible with brain sparing. Partial hemolysis, elevated liver enzymes, low platelet count (HELLP) syndrome was the hypothesis, and a cesarean section was performed. On day 2, the white-cell count reached 33,730 , with decreased consciousness and mild respiratory distress. Tomography revealed both lungs with ground-glass opacities. Swab for COVID-19 polymerase chain reaction (PCR) was positive. Thrombocytopenia in patients with COVID-19 appears to be multifactorial, similar to what occurs in preeclampsia and HELLP syndrome. We assume that the synergism of these pathophysiological mechanisms could accelerate the compromise of maternal conditions and could be a warning to the obstetric practice.

O presente relato descreve o caso de uma gestante de 31 anos, gemelar dicoriônica com 31 semanas, com queixa de mialgia, icterícia e desconforto abdominal. A paciente não apresentava sintomas gripais como febre ou tosse e não tinha conhecimento de exposição ao COVID-19. Pressão arterial e saturação de oxigênio normais. Os exames laboratoriais apresentaram contagem de plaquetas de $218,000 \mathrm{~mm}^{3}$, ALT $558 \mathrm{IU}$ e creatinina $2.3 \mathrm{mg} / \mathrm{dl}$. Doppler compatível com centralização de um dos fetos. Síndrome
\end{abstract}

received

June 11,2020

accepted

August 3, 2020
DOI https://doi.org/

10.1055/s-0040-1718437. ISSN 0100-7203.
Copyright $(2020$ by Thieme Revinter

Publicações Ltda, Rio de Janeiro, Brazil
License terms

(c) (1) 

Palavras-chave
- pré-eclâmpsia
- síndrome HELLP
- trombocitopenia
- infecções por coronavírus
- complicações na gravidez

de hemolysis, elevated liver enzymes, low platelet count (HELLP) parcial foi a hipótese diagnóstica inicial e a cesariana foi realizada. No segundo dia, a paciente apresentou leucócitos de 33.730 com queda do nível de consciência e desconforto respiratório leve. A tomografia revelou opacidade pulmonar em vidro fosco bilateralmente. A pesquisa de COVID-19 por polymerase chain reaction (PCR)/swab teve resultado positivo. Trombocitopenia em pacientes com COVID-19 é multifatorial, semelhante ao que ocorre na pré-eclâmpsia e na síndrome HELLP. Acreditamos que o sinergismo da fisiopatologia das doenças em questão pode acelerar o comprometimento materno e deve servir de alerta para a prática obstétrica.

\section{Introduction}

The coronavirus disease 2019 (COVID-19), caused by the severe acute respiratory syndrome coronavirus 2 (SARSCoV-2), produces a respiratory and systemic illness. It can progress to a severe form of pneumonia in 10 to $15 \%$ of patients and lead to critical illness, with acute respiratory distress, multi-organ failure and eventually intravascular coagulopathy. To identify these patients and optimize care, biomarkers are urgently needed for actively monitoring illness severity. ${ }^{1}$

Lippi et $\mathrm{al}^{1}$ showed that platelet count is a simple and readily available biomarker, which is independently associated with disease severity and risk of mortality in the intensive care unit (ICU). Besides, thrombocytopenia correlates with higher disease severity scores, and it was reported to occur in up to $55 \%$ of patients and was identified as a significant risk factor for mortality. ${ }^{1}$

Preeclampsia is a complex medical disorder; worldwide, each year, it is responsible for $>500,000$ fetal and neonatal deaths and $>70,000$ maternal deaths. Preeclampsia can deteriorate rapidly and without warning. ${ }^{2}$ Proteinuria is not mandatory for a diagnosis of preeclampsia. Rather, this is diagnosed by the presence of de novo hypertension after 20 weeks' gestation accompanied by proteinuria and/or evidence of maternal acute kidney injury, liver dysfunction, neurological features, hemolysis or thrombocytopenia, or fetal growth restriction. Preeclampsia may develop or be recognized for the first time intrapartum or early postpartum in some cases. ${ }^{2}$

Hemolysis, elevated liver enzymes, low platelet count (HELLP) is the combination of all or some of hemolysis, elevated liver enzymes and thrombocytopenia and is often referred to as the HELLP syndrome. For clinicians familiar with the management of preeclampsia, this constellation of abnormalities signifies a more serious part of the spectrum of this disorder. ${ }^{2}$

\section{Case Report}

A 31-year-old primigravida from Guarulhos, SP, Brazil, with dichorionic twins at 31 weeks, presented at the emergency room with 1-day history of general body pain (myalgia), jaundice, darkening of the urine and diffuse abdominal discomfort. She had no medical history, normal prenatal visits, and had received aspirin and calcium. She had no flu- like symptoms, including fever and cough, nor difficulty breathing and was not aware of exposure to COVID-19. She was afebrile. Her respiratory rate was $16 /$ minute, blood pressure of $110 \times 60 \mathrm{~mm} \mathrm{Hg}$ and $\mathrm{O}_{2}$ saturation of $98 \%$. Uterine activity was absent.

The heart rate in antepartum cardiotocography tracings was abnormal (category III-recurrent late decelerations) in both fetuses. For the male fetus, Doppler ultrasound was abnormal with reducing cerebrovascular impedance, compatible with brain sparing.

Laboratory tests showed a white-cell count of 17,170 and platelet count of $218,000 \mathrm{~mm}^{3}$. The C-reactive protein level was 2,5 and the liver function tests showed alanine aminotransferase (ALT) $558 \mathrm{IU}$ and total bilirubin $9.28 \mathrm{mg} / \mathrm{dl}$. Lactate dehydrogenase was $1,000 \mathrm{UI} / \mathrm{l}$, serum creatinine was $2.3 \mathrm{mg} / \mathrm{dl}$, and urine dipstick showed negative. Preeclampsia (PE) and partial HELLP syndrome was the hypothesis at that moment, associated to impairment of the twins. A cesarean section was performed without complications. Four hours after the procedure, a spike in blood pressure $(220 \times 120 \mathrm{mmHg})$ was detected associated to a hematoma of the abdominal wall that needed a surgical repair. The hypertensive emergency was controlled with $\mathrm{MgSO} 4$ and sodium nitroprusside. From then on, conditions have remained stable.

On day 2, the white-cell count reached 33,730, with decreased consciousness and mild respiratory distress. With the hypothesis of an infectious site, examinations were performed. Chest tomography revealed both lungs with ground-glass opacities and pleural effusion (-Fig. 1). An oropharyngeal swab for COVID-19 polymerase chain reaction (PCR) testing was positive. The patient was admitted to the intensive care unit (ICU) with $\mathrm{O}_{2}$ saturation $94 \%$ and maintained adequate saturation just with face mask oxygen. In the following days, the patient remained stable with improvement in laboratory tests, except for platelets, which reached the worst level on the day $9\left(49,000 \mathrm{~mm}^{3}\right)$. Thereafter, the exams returned to normal, with discharge from the ICU on day 14 with platelets of $121,000 \mathrm{~mm}^{3}$, ALT 58 , total bilirubin $2.9 \mathrm{mg} / \mathrm{dl}$ and creatinine $0.8 \mathrm{mg} / \mathrm{dl}$. On day 21 , she was discharged from the hospital.

The male fetus, who was born weighing $1,350 \mathrm{~g}$, died on the 16th day due to intracranial hemorrhage. The female fetus, who was born weighing $1,190 \mathrm{~g}$ (NGA), remains in the neonatal care unit with good evolution. The macroscopic appearance of the placentas was normal, but no microscopic 

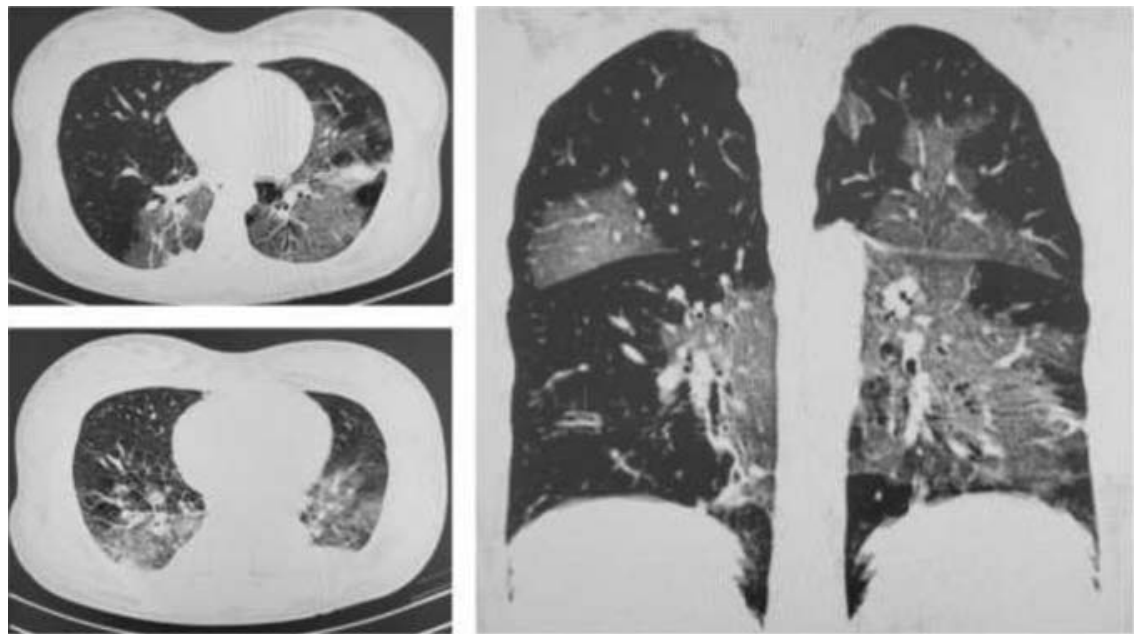

Fig. 1 Chest tomography showing extensive pulmonary involvement.

study was performed. The COVID-19 tests were negative in both newborns.

\section{Discussion}

Given the initial set of maternal clinical and laboratory information added to the fetal conditions, the diagnosis of HELLP syndrome seemed plausible, and the decisions followed recommendations in the face of an unsafe condition for mothers and babies. However, the sequence of events in this case suggests, although without strong evidence, that COVID-19 may have been a factor associated with hemolysis and thrombocytopenia. Many clinical and laboratory aspects of this new emerging infection are not yet fully understood, and several clinical expressions are observed, from asymptomatic conditions to critical and rapidly lethal situations.

Thrombocytopenia in patients with COVID-19 appears to be multifactorial, including endothelial damage, platelet activation with aggregation and thrombosis, impairment of bone marrow and megakaryocyte activity. It may also be due to changes in the pulmonary capillary bed morphology, which may lead to platelet defragmentation., ${ }^{1,3}$ Endothelial damage, platelet activation, and thrombosis are similar to what occurs in preeclampsia and HELLP syndrome.

This is an intriguing case of a pregnant woman with risk factors for preeclampsia (twin pregnancy and first pregnancy), admitted with the hypothesis of partial HELLP syndrome, having received appropriate treatment for this situation. However, subsequent events led to the COVID-19 diagnosis. Hemolysis, elevated liver enzymes, low platelet syndrome is a serious obstetric disease with general inflammatory activation, and it can progress to extensive endothelial damage and thrombocytopenia, with a high rate of maternal and fetal problems. ${ }^{2}$ It would be reasonable to assume that the synergism of these pathophysiological mechanisms could accelerate the compromise of maternal conditions. In addition, prophylactic administration of low-dose aspirin to pregnant women is common.

Despite the uncertainties, based on this case, we assume that the synergism of these pathophysiological mechanisms could accelerate the compromise of maternal conditions and could be a warning to the obstetric practice.

Given the current scenario, it is reasonable to assume that COVID-19 infection may be one of the causes of thrombocytopenia in pregnant women and with a high risk for serious problems. Fortunately, in the present case, the patient had a good response to treatment.

\section{Conflict of Interests}

The authors have no conflict of interests to declare.

\section{Acknowledgments}

We would like to thank Prof. Chris Redman for the precious comments on this case.

\section{References}

1 Lippi G, Plebani M, Henry BM. Thrombocytopenia is associated with severe coronavirus disease 2019 (COVID-19) infections: A meta-analysis. Clin Chim Acta. 2020;506:145-148. Doi: 10.1016/ j.cca.2020.03.022

2 Brown MA, Magee LA, Kenny LC, Karumanchi SA, McCarthy FP, Saito S, et al; International Society for the Study of Hypertension in Pregnancy (ISSHP). Hypertensive disorders of pregnancy: ISSHP classification, diagnosis, and management recommendations for international practice. Hypertension. 2018;72(01): 24-43. Doi: 10.1161/HYPERTENSIONAHA.117.10803

3 Zulfiqar AA, Lorenzo-Villalba N, Hassler P, Andrès E. Immune thrombocytopenic purpura in a patient with Covid-19. N Engl J Med. 2020;382(18):e43. Doi: 10.1056/NEJMc2010472 